\title{
Ethnic Factor in Reproductive and Marriage Behavior of Modern Russian Youth
}

Irina Sovetovna Karabulatova ${ }^{1}$

Irina Sergeevna Vasilyeva ${ }^{2}$

Svetlana Dmitrievna Galiullina ${ }^{3}$

Svetlana Aleksandrovna Nikonova ${ }^{3}$

Olga Nikolaevna Budeeva ${ }^{3}$

\author{
1 Institute of Social and Political Research of the Russian Academy of Sciences, 32A, Leninsky prospect, Moscow \\ 2Moscow State Forest University; ${ }^{3}$ Ufa State University of Economics and Service, 450078, Ufa, Chernyshevsky St., 145
}

Doi:10.5901/mjss.2015.v6n6s3p104

\begin{abstract}
Complexity of this process defines the variety of models of the premarital relations and a choice of the wedding partner described by science. Research the process of selecting a mate and premarital relations, in our view, can be divided into several types associated with a gender approach (Arkhipova, 2006; Ryazantsev, et al, 2014 \& Van Peer, 2002). Results of research can form a basis of further studying of the nature of the premarital relations, valuable installations of a choice of the marriage partner. The received results can be used in the sphere of sociology, social work, pedagogics, psychology, etc. The practical practices and recommendations containing in the thesis can be used in activity of government bodies of the power, governing bodies for development of family policy, the higher education institutions, schools, social services and the centers, any other institutions working with youth and a family for planning and the organization of systematic, purposeful preparation of the younger generation for marriage and family life, and also for development of federal, regional, local projects and programs. Some provisions of work can be useful when developing the special training courses focused on the preparation of youth for marriage and family life.
\end{abstract}

Keywords: Russian youth, ethnos, marriage, family, premarital behavior.

\section{Introduction}

The premarital relations of young people are formed in the course of premarital behavior and directed on satisfaction of various needs of the identity of the relation that represent set of the repeating interactions between young partners. Modification of stereotypes of premarital and family behavior of modern youth at a stage of a choice of the marriage partner is staticized as a social phenomenon as a result of real development of social, psychological and moral readiness of modern youth for the wedding and family life which happens under the influence of constant objective factors: parental family, culturological features of the country (region), all educational system, specific features of character of individuals (Höhn, 2001; Ryazantsev, et al 2015; Kazarina-Volshebnaya, Komissarova \& Turchenko, 2012 \& Karabulatova, 2004). Urgent need of modern Russian society is development of constantly operating state program, and also methods of optimization of preparation of youth for marriage and family life both on federal, and on local levels for the purpose of creation of the necessary conditions favoring to strengthening of a young family.

The modern matrimony imposes more difficult requirements to the personal interaction of family members. In a family-weakening of the social and psychological effect of a community, a strong connectedness that provokes a rupture of continuity between generations happens the increasing speed. The youth in these conditions finds moral values in many respects independently. If in the historical past the choice of the marriage partner was defined by interests of a sort, family, estate, and the individual submitted to the stereotypes accepted in society, today the youth is in many respects free in the premarital behavior. The sphere of communication of modern young people becomes more selective and differentiated. Valuable orientations of young men and girls lose matrimonial monopoly: the love, emotional contacts, and sexual satisfaction represent for them independent values, not always, the families connected with education. Being the most active part of society, the youth through the relation to matrimonial values defines the principles of the premarital relations. 


\section{Materials and Methods}

In this research, both primary, and secondary material is used. Treat data of the secondary analysis of sociological researches: a) Pereverzeva O. V. "Premarital relations of youth: valuable aspect"(Maikop, 2012, N=456 people);b) Burkhanova F.B. "Family and marriage installations and values of modern student's youth" (Ufa, 2001. N=766 persons); c) Burkhanova F.B., Valiakhmetov R. M., Hilazheva G. F. "A family and human development in the Republic of Bashkortostan" (Ufa, 2012, N=1225 people); d) «Family and birth rate in Lithuania" (Poll in Lithuania in 1994-1995 is carried out by Baltijos tyrimai firm. 5000 respondents of women and men at the age of 18-49 years are interrogated); e) "Assessment of population policy" of 2010 (Second European Comparative Survey on the Acceptance of Populationrelated Policies (PPA2)); Federal Institute of demographic researches (Germany) coordinated the project. 14 countries of Europe participated in the research. 14000 respondents at the age of 18-75 years are interrogated; e) the sociological data obtained by Russian Public Opinion Research Center (VTsIOM), Institute of Sociology of the Russian Academy of Sciences, Levada's Center. Primary author's material is created during multicomponent complex interviewing with the subsequent analysis. Primary sociological research is conducted on the subject "Valuable Installations of a Choice of the Marriage Partner". The sample included 500 respondents, is carried out in 2012-2013 by the author among the youth, which is trained in the senior classes of schools, lyceums, colleges, higher education institutions of the Moscow region, and the working youth. Selection quote (according to the social status and gender structure, on age and education). A sociological survey in the form of questioning with the participation of young respondents from the Moscow region aged from 15 till 29 years was conducted. Respondents were divided into five groups of 50 young men and 50 girls in each group:

1 - Pupils of the senior (10-11) classes of 100 people (50 young men and 50 girls) Municipal Budgetary Educational Institution (MBEI) of high comprehensive school (SOSh) No. 25, city Mitishchi, Moscow region, Municipal Educational Institution (MEI) of Lyceum No. 15 of department of national education of the Mytishchi area, Moscow region, Municipal Educational Institution (MEI) of the high comprehensive school (HCS) No. 12, city Korolev, Moscow region;

2 - Pupils of NPO Professional Public Educational Institution of Lyceum No. 26 of S.P. Korolev city Korolev, Moscow region and MBOU of Lyceum No. 2 of the Mytishchi municipal area, the Moscow region 100 people (50 young men and 50 girls)

3 - The studying colleges of 100 people (50 young men and 50 girls): The Mytishchi machine-building technical school, the Moscow cooperative technical school of G. M. Altshul, Royal College of space mechanical engineering and technologies;

4 - 100 University students (50 boys and 50 girls) day and distance learning: VPO Moscow State Forest University, VPO Russian State University of Tourism and Service, and some other Moscow universities, VPO Moscow State Technical University. Bauman and VPO Moscow State Construction University (before 1993. Moscow Engineering and Construction Institute. Kuibyshev);

5 - The working youth of 100 people ( 50 young men and 50 girls). Representatives of various areas and spheres of a production activity took part in poll (Kobersy et al., 2015): medical, pharmaceutical, cosmetic, financial, building, administrative, educational, trade, metal-working, food industry, wood-processing industry, etc.

At poll, the questionnaire consisting of 40 questions covering the relation of the premarital and family relations interrogated to problems was developed and applied. Answers of Respondents are processed using a software package of SPSS.

The second research was conducted in September-October, 2013. 366 people, quote selection, 183 couples consisting in the premarital relations, representatives of various nationalities from 18 to 30 years was captured.

A third study - conducted interviews with youth megacity (Moscow) at the age of 28-30 years on "pre-marital sex among young people in the city" (sample size of 28 people, the target sample), the SEC "RIO" and "SportEX", July 2012.

The fourth research - deep interview "The premarital relations of the youth of the megalopolis and rural areas: norm or deviations?" it is carried out in May 2013. The method of family stories was used, 45 people from them consisting in 23 officially unregistered relations are interrogated.

The versatile and interdisciplinary character of a perspective of valuable installations of a choice of the marriage partner in the premarital relations of youth defines a variety of various sources used in work. 


\section{Results}

On a poll of 366 people - quote selection, consisting in the premarital relations, representatives of various nationalities (Table 1).

Table 1 - National structure

\begin{tabular}{|l|c|c|c|c|c|}
\hline In total 366th persons. Only 183 couples & $18-22$ & $23-26$ & $27-30$ & $\mathrm{~m} / \mathrm{f} / \mathrm{total}$ & Coincidence of couples on a nationality \\
\hline Russian $\mathrm{m} / \mathrm{f}$ & $18 / 28$ & $22 / 30$ & $18 / 24$ & $58 / 82 / 140$ & 48 \\
\hline Tatars $\mathrm{m} / \mathrm{f}$ & $18 / 10$ & $14 / 7$ & $4 / 4$ & $36 / 21 / 57$ & 20 \\
\hline Jews $\mathrm{m} / \mathrm{f}$ & $9 / 4$ & $4 / 9$ & $8 / 6$ & $21 / 19 / 40$ & 18 \\
\hline Ukrainians, Belarusians $\mathrm{m} / \mathrm{f}$ & $11 / 5$ & $2 / 7$ & $5 / 5$ & $18 / 17 / 35$ & 11 \\
\hline Azerbaijanians $\mathrm{m} / \mathrm{f}$ & $2 / 2$ & $2 / 3$ & $1 / 2$ & $5 / 7 / 11$ & 5 \\
\hline Armenians $\mathrm{m} / \mathrm{f}$ & $1 / 1$ & $1 / 1$ & $2 / 3$ & $4 / 5 / 9$ & 3 \\
\hline Tajiks, Uzbeks m/f & $1 / 1$ & $2 / 4$ & $2 / 3$ & $5 / 8 / 13$ & 2 \\
\hline Dagestanis, Adyghe, Ingush, Chechens $\mathrm{m} / \mathrm{f}$ & $8 / 12$ & $16 / 8$ & $12 / 4$ & $36 / 24 / 60$ & 18 \\
\hline & $68 / 63$ & $63 / 69$ & $52 / 51$ & $183 / 183$ & 125 coincidence from 183 couples \\
\hline
\end{tabular}

Because of the quite limited number of respondents, other numerous nationalities of Russia were not presented in all their variety in the set investigated by us.

One of the sociological factors of marriage selection is the territorial proximity.

More than $90 \%$ of all number of respondents' state, in general, the positive relation to joint life out of the registered marriage. Thus, it should be noted that among women aged from 27 till 30 years prevail. Joint distribution of opinions of grooms and brides showed that installations of future spouses coincide at $68 \%$ of couples, in $68 \%$ from which relation to cohabitation, in general, positive and in $2 \%$ the negative. Thus, we can speak about a change of valuable installations on the virginity fact at girls.

Also during poll installations of grooms and brides of rather premarital sexual relations were found out. From all respondents negatively concerning the sexual relations before marriage only $2 \%$ of respondents stated. The remained $98 \%$ consider the premarital sexual relations, in general, admissible. Among their opponents men $-2 \%$ to $1 \%$ prevail.

Let's notice that, according to our data, installations of rather joint life out of the registered marriage and premarital sexual behavior practically do not depend on education, the social status, a residence and characteristics of a parental family.

With the growth of some the divorced people, the question of the marriage status marrying is important. From all set of respondents, first marriage is entered by $81 \%$ of respondents. Thus, 12 of $19 \%$ of the divorced grooms and brides already have children from the previous marriages (Nikolaeva, Bogoliubova \& Shirin, 2015). Widows and widowers among respondents did not meet.

Data show that shares of the grooms and brides entering repeated marriage are equal - on average on $12 \%$ of that and others from all contingent. The difference between some men and women with children attracts attention. So, have children from the previous marriages of $11 \%$ of brides and only $1 \%$ of grooms.

One of the hypotheses of research said that the fact of migration of future spouses (Ryazantsev, et al, 2014; Ryazantsev, et al 2015 \& Ryazantsev, et al, 2015 a). In this regard, the respondent was offered to answer a question, how many years they live in Moscow. As it became clear, the fact of migration of one of the future spouses has no essential impact on a marriage choice of women in the age group from 27 to 30 years.

Marriages with an identical frequency consist in other age groups between all allocated categories: the aboriginals living in Moscow over 10 years from 5 to 10 years etc. (Table- 2)

Table 2 - Influence of migration on a marriage (\%)

\begin{tabular}{|l|c|c|c|c|c|c|}
\hline \multirow{2}{*}{ Age } & \multicolumn{2}{|c|}{$18-22$} & \multicolumn{2}{|c|}{$23-26$} & $27-30$ \\
& \multicolumn{2}{|c|}{$68 / 63$} & $63 / 69$ & \multicolumn{2}{|c|}{$52 / 51$} \\
\cline { 2 - 7 } & bride & groom & bride & groom & bride & groom \\
\hline Lives in Moscow over 10 years & 46 & 41 & 60 & 57 & 62 & 59 \\
\hline Lives in Moscow from 6 to 10 years & 16 & 10 & 14 & 14 & 16 & 17 \\
\hline Lives in Moscow from 1 to 5 years & 13 & 17 & 12 & 12 & 12 & 13 \\
\hline Lives in Moscow less than 1 year & 11 & 13 & 11 & 12 & 8 & 7 \\
\hline Lives in other city, the country, I have temporary registration & 14 & 19 & 3 & 5 & 2 & 4 \\
\hline
\end{tabular}


Their prevalence explains the big share of marriages between aboriginals (38\%) in a total number of respondents.

It should be noted that among aboriginals of the city there are more than women (62\% in age group from 27 to 30 years), and among those who lives in Moscow less than a year - men of $13 \%$ and $19 \%$ aged from 18 till 22 years.

In other categories of men and women approximately equally. Met also such who does not live in Moscow constantly, but, having a temporary registration, decided to register the marriage $-7,8 \%$ of all number of respondents.

The obtained data testify that the probability of a marriage is influenced a little by the coincidence of religious installations of future spouses, except for Tatars and the nationalities living in the Caucasus.

Thus, some unification of installations on some children in marriage is observed.

Table 3 - How many children would you like to have if all necessary conditions were for this purpose created?

\begin{tabular}{|l|c|c|c|c|c|c|c|c|c|c|c|c|}
\hline & \multicolumn{2}{|c|}{1 group } & \multicolumn{2}{c|}{2 group } & \multicolumn{2}{c|}{3 group } & \multicolumn{2}{c|}{ 4 group } & \multicolumn{2}{c|}{5 group } & \multicolumn{2}{c|}{ Total } \\
\hline & youths & girls & youths & girls & youths & girls & youths & Girls & youths & girls & youths & girls \\
\hline One & $24 \%$ & $12 \%$ & $12 \%$ & $4 \%$ & $4 \%$ & $16 \%$ & $4 \%$ & $4 \%$ & $12 \%$ & $4 \%$ & $11 \%$ & $8 \%$ \\
\hline Two & $32 \%$ & $32 \%$ & $68 \%$ & $60 \%$ & $68 \%$ & $36 \%$ & $40 \%$ & $56 \%$ & $44 \%$ & $44 \%$ & $50 \%$ & $46 \%$ \\
\hline Three and more & $20 \%$ & $32 \%$ & $4 \%$ & $32 \%$ & $20 \%$ & $36 \%$ & $40 \%$ & $20 \%$ & $24 \%$ & $36 \%$ & $22 \%$ & $31 \%$ \\
\hline Four and more & $12 \%$ & $16 \%$ & $16 \%$ & $4 \%$ & $8 \%$ & $12 \%$ & $12 \%$ & $20 \%$ & $16 \%$ & $16 \%$ & $13 \%$ & $14 \%$ \\
\hline
\end{tabular}

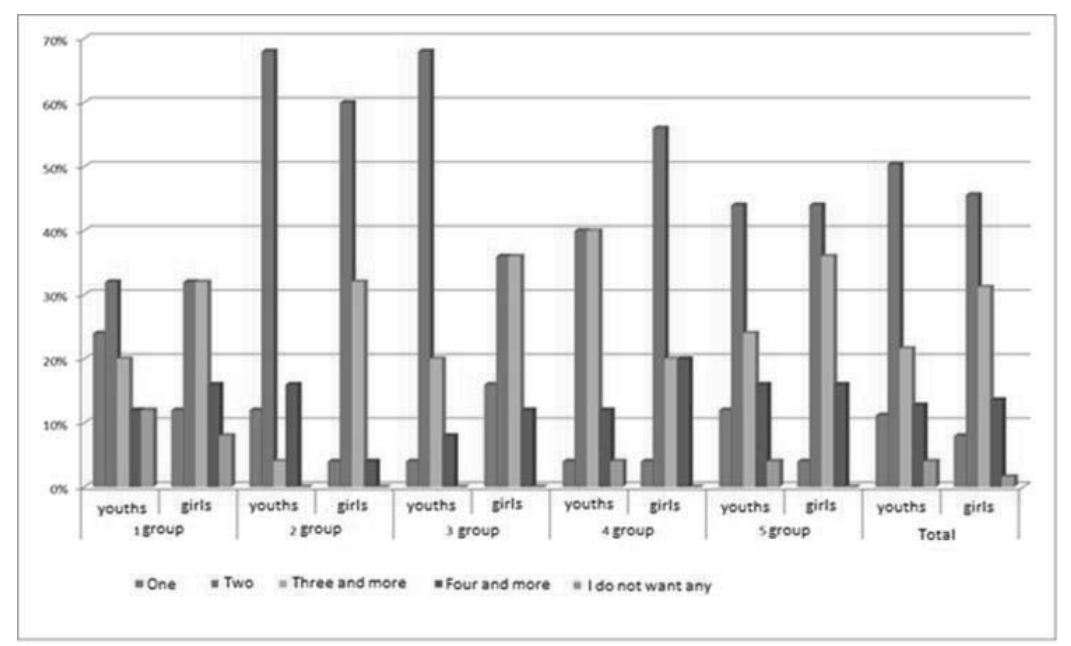

Figure 1 - How many children would you like to have if all necessary conditions were for this purpose created?

Concerning the age of respondents. Groups of youth were presented, since 15 years and finishing 30 for years. In our opinion, such selection allows making some predictive statements not only rather sexual and matrimonial behavior but also reproductive also that will allow revealing tendencies in a demographic situation in Russia.

Table 4 - Distribution of age of respondents

\begin{tabular}{|c|c|c|c|c|c|c|c|c|c|c|c|c|}
\hline & \multicolumn{2}{|c|}{1 group } & \multicolumn{2}{c|}{2 group } & \multicolumn{2}{c|}{3 group } & \multicolumn{2}{c|}{4 group } & \multicolumn{2}{c|}{5 group } & \multicolumn{2}{c|}{ Total } \\
\hline & youths & girls & youths & girls & youths & girls & youths & Girls & youths & girls & Youths & girls \\
\hline 15 year & $4 \%$ & $4 \%$ & - & $4 \%$ & - & - & - & - & - & - & $1 \%$ & $2 \%$ \\
\hline 16 year & $44 \%$ & $24 \%$ & $16 \%$ & $16 \%$ & $28 \%$ & $20 \%$ & - & - & - & - & $18 \%$ & $12 \%$ \\
\hline 17 year & $36 \%$ & $32 \%$ & $32 \%$ & $24 \%$ & $48 \%$ & $72 \%$ & - & - & - & - & $23 \%$ & $26 \%$ \\
\hline 18 year & $16 \%$ & $40 \%$ & $28 \%$ & $44 \%$ & $24 \%$ & $8 \%$ & $16 \%$ & $12 \%$ & - & - & $17 \%$ & $21 \%$ \\
\hline 19 year & - & - & $16 \%$ & $8 \%$ & - & - & $40 \%$ & $36 \%$ & - & - & $11 \%$ & $9 \%$ \\
\hline 20 year & - & - & $8 \%$ & - & - & - & $24 \%$ & $24 \%$ & $4 \%$ & $8 \%$ & $7 \%$ & $6 \%$ \\
\hline 21 year & - & - & - & - & - & - & $16 \%$ & $20 \%$ & - & $12 \%$ & $3 \%$ & $6 \%$ \\
\hline 22 year & - & - & - & - & - & - & $4 \%$ & $8 \%$ & $4 \%$ & $4 \%$ & $2 \%$ & $2 \%$ \\
\hline
\end{tabular}




\begin{tabular}{|c|c|c|c|c|c|c|c|c|c|c|c|c|}
\hline 23 year & - & - & - & - & - & - & - & - & $20 \%$ & - & $4 \%$ & - \\
\hline 24 year & - & - & - & - & - & - & - & - & $8 \%$ & $20 \%$ & $2 \%$ & $4 \%$ \\
\hline 25 year & - & - & - & $4 \%$ & - & - & - & - & $16 \%$ & $8 \%$ & $3 \%$ & $2 \%$ \\
\hline 26 year & - & - & - & - & - & - & - & - & $12 \%$ & $20 \%$ & $2 \%$ & $4 \%$ \\
\hline 27 year & - & - & - & - & - & - & - & - & $28 \%$ & $16 \%$ & $6 \%$ & $3 \%$ \\
\hline 28 year & - & - & - & - & - & - & - & - & $8 \%$ & $8 \%$ & $2 \%$ & $2 \%$ \\
\hline 29 year & - & - & - & - & - & - & - & - & - & $4 \%$ & - & $1 \%$ \\
\hline
\end{tabular}

For various ethnic groups acquaintance through the mediation of parents, acquaintances are still preferable. At the same time, the era of globalization and the Internet expands possibilities of setting of acquaintances of the intimate and personal plan that can lead as to steady intimate relations, and marriage subsequently.

Table 5 - Where you got acquainted with your elect (darling)?. (\% of total of young men and girls on each of five groups)

\begin{tabular}{|c|c|c|c|c|c|c|c|c|c|c|c|c|}
\hline & \multicolumn{2}{|c|}{1 group } & \multicolumn{2}{|c|}{2 group } & \multicolumn{2}{|c|}{3 group } & \multicolumn{2}{|c|}{4 group } & \multicolumn{2}{|c|}{5 group } & \multicolumn{2}{|c|}{ Total } \\
\hline & youths & girls & Youths & girls & youths & Girls & youths & girls & youths & girls & youths & girls \\
\hline In vacation spots and carrying out leisure & $24 \%$ & $20 \%$ & $28 \%$ & $16 \%$ & $28 \%$ & $16 \%$ & $12 \%$ & $36 \%$ & $28 \%$ & $36 \%$ & $24 \%$ & $25 \%$ \\
\hline On the street, in transport & $12 \%$ & $4 \%$ & $12 \%$ & $16 \%$ & $24 \%$ & $8 \%$ & $4 \%$ & $4 \%$ & $20 \%$ & $4 \%$ & $14 \%$ & $7 \%$ \\
\hline Acquainted by parents, relatives & $4 \%$ & $8 \%$ & $4 \%$ & - & $8 \%$ & $8 \%$ & $8 \%$ & - & $4 \%$ & $4 \%$ & $6 \%$ & $4 \%$ \\
\hline At school & $36 \%$ & - & $4 \%$ & - & $8 \%$ & $16 \%$ & $16 \%$ & $24 \%$ & $4 \%$ & - & $14 \%$ & $8 \%$ \\
\hline In higher education institution & $4 \%$ & $4 \%$ & $20 \%$ & $16 \%$ & - & $16 \%$ & $16 \%$ & $20 \%$ & $16 \%$ & $4 \%$ & $11 \%$ & $12 \%$ \\
\hline Live on one street, in one house & $20 \%$ & $4 \%$ & $4 \%$ & $8 \%$ & - & $8 \%$ & - & - & - & $36 \%$ & $5 \%$ & $11 \%$ \\
\hline Gave another answer & - & - & $20 \%$ & $28 \%$ & - & $16 \%$ & - & $16 \%$ & $28 \%$ & - & $10 \%$ & $12 \%$ \\
\hline None chosen & - & $60 \%$ & $8 \%$ & $16 \%$ & $32 \%$ & $12 \%$ & $44 \%$ & - & - & $16 \%$ & $17 \%$ & $21 \%$ \\
\hline On the street, in transport & $12 \%$ & $4 \%$ & $12 \%$ & $16 \%$ & $24 \%$ & \begin{tabular}{|l|l|}
$8 \%$ \\
\end{tabular} & $4 \%$ & $4 \%$ & $20 \%$ & $4 \%$ & $14 \%$ & $7 \%$ \\
\hline
\end{tabular}

It should be noted that today selectivity of acquaintances caused creation on the Internet of the specialized sites directed on acquaintance of people to orientation: a) on a nationality, the country; b) on confessional accessory (acquaintances to Muslims and for Muslims, Christian acquaintances, acquaintances for Caucasians, acquaintances for Jews, etc.); c) on specific features of people (acquaintance for persons with disabilities, etc.). The closeness of separate groups does not allow carrying out deeper interviewing. However, the intensity in society creates installations in search of the partner in the ethnic group. When analyzing gender characteristics, it is possible to allocate some parameters, directly and indirectly promoting or interfering the introduction in the premarital relations. To the forefront, there are what raise their selfassessment, first, in the opinion of a future spouse, and people around. The existence of the apartment, a wage level and the educational qualification concern to them. For women, it also presence of children and a nationality. The relation to the education standards of the woman can be various from the woman and her elect (Dyurgeym, 1996).

Women are having premarital relations, mostly Russian. A group of women who were not married is multinational. The difference in nationality is a significant obstacle to marriage for women. Probably from the fact that men primarily see them as future mothers for their children.

Overall, the nationality of the men does not affect the solution of personal problems, while the group of "successful" men are more multinational. Internationality among entered premarital sex is much more prevalent in men than in women, mainly of Russian origin.

However, higher social and economic status leads to the search for a more attractive partner for various qualities (attractiveness and financial viability, youth, health, education, etc.), where the ethnic factor ceases to play a decisive role in choosing the marriage partner.

\section{Discussion}

In domestic and foreign the family maintaining two mutually exclusive positions on an occasion of a condition of a family in modern society compete. One of them considers that the monogamy as that - is lost, the family endures the deep crisis, the institute of a family becomes obsolete. The scientists are taking another position claim that in a family there are active transformational processes. In the direction of studying of modern transformations in a family researchers as in Russia, so in the near and far abroad actively work (Karepova et al, 2015 \& Ostrovskaya et al, 2001). There is a problem of a choice of standards of behavior, preference of ethnos in an inner world of the individual (Karabulatova, 2013; Karabulatova \& Polivara, 2013; Khachmafova et al, 2015 \& Gabdrafikov et al, 2015). 
The term "marriage" which is applied to this research, designates the long-term, steady, authorized by society relations living together men and women. In this definition of "sanctioning society," it is reflected both the social acceptability of the unregistered unions, and lawful registration of these relations. (However, in ordinary consciousness the word "marriage" as it became clear from results of interviewing, is associated rather with lawful registration, than with the actual matrimony.) Therefore, it would be possible to call the studied phenomenon more precisely "marriage-like relationship". Domestic sociologists pay attention to five main types of the motivation of the premarital relations: love, spiritual proximity, material calculation, psychological adequacy and moral reasons. Psychologists allocate one more group of motives, which is not realized by partners: a community of interests, intimate, good luck, and mutual easy availability, benefit, fear of loneliness, pity, revenge.

The orientation of research of the premarital relations develops under the influence of scientific discussions about a condition of a modern family: whether the family endures deep valuable and motivational crisis owing to what the institute of a family becomes obsolete; or in modern Russian society, as well as in many foreign countries, there are transformational processes. In scientific works that investigate the premarital relations, questions of institutional changes of the family and marriage relations, problems of the transformation of a family that is followed by modifications of its functions are considered.

The premarital relations are considered as the complex process including two main versions: appointments and cohabitation (Veyninger, 1991). These relations possess similarities in questions of privacy, extreme intensity and an emotional involvement of partners. Further, it is noted that during the premarital period values, motivations, behavior models, which will directly or indirectly be shown further in the matrimonial relations, are formed.

\section{Conclusion}

The youth, which is in the premarital relations most, is in great need for special attention, and studying of their way of life and the main problems, which can furnish the clue to understanding of processes of transformation of institute of a family in general, its places in modern Russian society. Based on results of the conducted research it is possible to draw a conclusion that the changes in the sphere of a family taking place represent a certain modernization and are a stage of evolution of a family as institute, but not its decline. These data are correlated with the results received by other researchers (Ryazantsev et al, 2014; Zider, 1997; Golod, 2004; Postl, 2003; Antonov, 2000 \& Cliquet Robert, 2015). This stage represents the process of strengthening of the institutional essence of a family, which corresponds to today's public requirements. Materials of this research show that the majority of couples living together without official registration do not refuse a family as that, and opposite, show obvious aspiration to it that the care of children and about each other confirms them.

The portrait of the average respondent making a choice of the marriage partner contains the following characteristics (Table 6).

Table 6 - Key features of youth, making a marriage choice

\begin{tabular}{|c|c|c|c|c|c|c|c|}
\hline \multirow{2}{*}{ № } & \multirow{2}{*}{$\begin{array}{l}\mathrm{N}=366 \text { persons } \\
\text { Name }\end{array}$} & \multicolumn{3}{|c|}{ Men N=140 } & \multicolumn{3}{|c|}{ Women $\mathrm{N}=226$} \\
\hline & & 16-19 year & 20-24 years & $25-29$ years & 16-19 year & 20-24 years & 25-29 year \\
\hline 1. & Presence of children: & & & & & & \\
\hline & - 1 child & 1 & 3 & 5 & 2 & 5 & 21 \\
\hline & - 2-3 childrens & 0 & 1 & 2 & 1 & 2 & 19 \\
\hline & - there are no childrens & 42 & 43 & 43 & 95 & 35 & 46 \\
\hline 2. & Education: & & & & & & \\
\hline & - high & 0 & 31 & 30 & 0 & 48 & 25 \\
\hline & - secondary & 20 & 6 & 5 & 11 & 65 & 41 \\
\hline & - secondary special & 23 & 21 & 21 & 14 & 10 & 12 \\
\hline 3. & Salary: & & & & & & \\
\hline & - high & 11 & 16 & 21 & 8 & 12 & 10 \\
\hline & - average & 15 & 21 & 19 & 13 & 35 & 59 \\
\hline & - low & 18 & 10 & 9 & 44 & 23 & 22 \\
\hline 4. & Growth: & & & & & & \\
\hline & - up to $169 \mathrm{~cm}$ & 13 & 18 & 14 & 48 & 45 & 39 \\
\hline & - from 170 to $180 \mathrm{~cm}$ & 15 & 21 & 23 & 29 & 31 & 23 \\
\hline & - above $181 \mathrm{~cm}$ & 8 & 9 & 19 & 2 & 4 & 5 \\
\hline
\end{tabular}




\begin{tabular}{|c|c|c|c|c|c|c|c|}
\hline \multirow[t]{3}{*}{5.} & \multicolumn{7}{|l|}{ Nationality: } \\
\hline & - Russian & 34 & 30 & 30 & 53 & 47 & 44 \\
\hline & - other nationalities & 14 & 11 & 21 & 29 & 31 & 22 \\
\hline \multirow[t]{4}{*}{6.} & Housing: & & & & & & \\
\hline & - private apartment & 11 & 21 & 32 & 9 & 27 & 39 \\
\hline & - room in a residence & 14 & 11 & 4 & 28 & 13 & 11 \\
\hline & - with parents & 22 & 15 & 10 & 43 & 29 & 27 \\
\hline \multirow[t]{5}{*}{7.} & The period of residence in the megalopolis or in area: & & & & & & \\
\hline & - from birth & 10 & 9 & 11 & 17 & 28 & 21 \\
\hline & - from 1 to 5 years & 13 & 10 & 16 & 13 & 15 & 21 \\
\hline & - от 6 до 9 лет & 10 & 8 & 13 & 18 & 19 & 16 \\
\hline & - over 10 years & 12 & 14 & 14 & 19 & 22 & 17 \\
\hline \multirow[t]{3}{*}{8.} & Were previously married: & & & & & & \\
\hline & - yes & 12 & 8 & 10 & 15 & 23 & 23 \\
\hline & - no & 61 & 21 & 28 & 70 & 51 & 44 \\
\hline
\end{tabular}

Prevalence of women ( 25 years are more senior) concerning selection that attracts to pay attention. Apparently, with age it becomes harder to women to be acquainted owing to the smaller number of the men suitable them on age and not married. Along with it at them affiliative requirements increase: there is a desire to establish a family, to have children, especially if they have no them.

Most of the men, who treat age group 25-29-year-old, were married earlier. However, after divorce do not hurry to establish the marriage relations as the stereotypic opinion is widespread that to the man never late to marry that all life ahead. Need to be prepared for family life, to find a profession, the social status, housing, etc. affects. Let's note that men prefer women of younger age more often. Quite often, it is connected with the desire to have children in the new relations. Often their claims are obviously overestimated that testifies to an inadequate self-assessment of men.

About 33\% of women at the age of 20-25 years do not plan a choice of the marriage partner, but allow registration of the premarital relations for the short period. It is characteristic of the women living over 5 years in the megalopolis. As for the women of this age group living in an area that, they, on the contrary, plan a choice of the marriage partner, approve the premarital relations on condition of the conclusion of the official marriage. In view of that the developed demographic situation not in favor of women at the age of 25-30 years, - the small choice of the possible partner of the corresponding age, brings to loss of hope to enter a stage of registration of the premarital relations and then to register the relations.

Let's note that young women (till 30 years) more willingly, than men of their age, often take active living position, trying to solve independently personal problems, but quite often experience difficulties in the partner's choice.

Women more often than men, make a selection of the marriage partner and try to establish a family. However, men of the age group of 25-29 years get more purposeful marriage motivation, considering these attempts as the last chance. Also, if some of them directly speak about it, others try to make an impression of the person passionless, for which choice of the marriage partner and creation of a family not so considerably.

The difficult demographic situation consisting in depopulation, which is observed not only in Russia but also in other European countries, staticizes a problem of the scientific analysis of the matrimonial relations. At the present stage feature of the development of the matrimonial relations is a large number of divorces, legitimization of the premarital relations, increase in a number of illegitimate children (Fernkhem \& Heyven, 2001).

Marriage choice, being the first and key stage of formation of a family, has crucial importance for its further development, after all many risk factors of destruction of marriage take place already at the time of its conclusion (Phillips, 2002). Based on the conducted author's research the conclusion of sociologists is confirmed that young people in the majority are focused on a family and the family relations (The future of families to 2030 projections, policy challenges and policy options, 2015). The family acts as the leading values of modern Russian society.

It is revealed that the gender model of premarital relationship is evident in the sphere of the division of labor, power, emotional and sexual relationship with the persistence of gender asymmetry. In the system of values, correlate Patriarchate, and egalitarian components. There was a strengthening matriarchate values, the elevation of women's status in the family, its role in revenue management.

The premarital relations of youth represent set of the repeating interactions between young partners who are directed to satisfaction of various needs of the personality (Kohn, 2010; McDonald, 2000; Karabulatova, et al, 2015 \& Giddens, 2004). The premarital relations of youth (till 30 years) represent the experimental, economic and household and sexual union in common living women and men, giving the chance to check partners for compatibility, for their readiness 
for full marriage, and also the certain social competences obligatory of family life promoting acquisition. For other age groups (after 30 years) to consider expediently premarital relations as cohabitation.

The marriage is the significant event in the life of the personality influencing her further destiny. It will be coordinated with understanding of this vital event as the rotary stage connected with the adoption of important decisions for the long period of life (Pereverzeva, 2012; Zdravomyslova 2003).

The premarital relations represent a gender phenomenon, which possesses a number of features: has asymmetry - a certain inequality at a stage of a choice of the partner and at the beginning of formation of the premarital relations. The premarital relations are perceived by youth as the social norm or a deviation depending on gender and age signs, ethnic-confessional accessory, type of the settlement, education, living conditions, a financial solvency, presence of children and possibility of a child-bearing.

\section{References}

Antonov, A.I. \& Sorokin S.A. (2000) Destiny of a family in Russia the XXI century. M.: "Graal". pp. 416.

Arkhipova, E. (2006) Crises of family life. To.: prod. "Fares," 2006. pp. 94-128.

Veyninger, O. (1991) Paul and character. The man and the woman in the world of passions and sensuality. The lane with it. - M.: Forum XIX-XX-X1X. pp.192.

Gabdrafikov, I.M., Karabulatova, I.S., Khusnutdinova, L.G. \& Vildanov Kh.S. (2015) Ethnoconfessional Factor in Social Adaptation of Migrant Workers in the Muslim Regions of Russia. In the: Mediterranean Journal of Social Science. 2015. Vol 6, No3, Supplement 4, May 2015. pp. 213-223.

Giddens, E. (2004) Transformation of intimacy. / the Translation from English V. F. Anurin. SPb.: St. Petersburg. pp. 208.

Golod, S.I. (2004) Sexuality, gender and family: sociological interpretation / Part 1. / Person. No. 4. pp. 113-123.

Dyurgeym E.Education sociology: Translation from French by T.G. Astakhova's (1996) Scientific editor V.S. Sobkin, V.Ya. Nechayev. M.: INTOR. pp. 80.

Nikolaeva, J. V., Bogoliubova, N. M., \& Shirin, S. S. (2015). Ecological tourism in the state image policy structure. experience and problems of modern Russia. Current Issues in Tourism, doi:10.1080/13683500.2015.1100588

Zdravomislova, O.N. (2003) Family and society: Gender measurements of the Russian transformation. M.: Editorial of URSS.

Zider, R. (1997) Social history of a family in the Western and the Central Europe (the end of the XVIII-XX centuries) / the Translation from German by L.A. Ovchintseva's; scientific editor M. Yu. Brandt. - M.: VLADOS humanitarian publishing center. pp. 302.

Karabulatova, I.S. (2004) Culture of the childhood of the Tyumen region: traditions and present. Tyumen: Akademiya publishing house. pp. 268.

Karabulatova, I.S. (2013) The problems of linguistic modeling of new Eurasian linguistic personality in the multilinguistic and mental environment (by the example of onomasphere).In the: Middle-East Journal of Scientific Research 17 (6): 791-795.

Kobersy, I., Karyagina, A., Karyagina, O., \& Shkurkin, D. (2015). Law as a Social Regulator of Advertisement and Advertising Activity in the Modern Russian Information Space. Mediterranean Journal Of Social Sciences, 6(3 S4), 9. Retrieved from http://www.mcser. org/journal/index.php/mjss/article/view/6705

Karabulatova, I.S. \& Polivara Z.V. (2013) Turkic, and Slavs: bi-polylinguism in globalization and migrations (on an example of Tumen region). In the: Middle-East Journal of Scientific Research 17 (6): 832-836.

Kazarina-Volshebnaya, E.K., Komissarova, I.G. \& Turchenko V.N. (2012) Paradoxes of the transformation of valuable orientations of the Russian youth. In the: Soc. № 6, pp. 120-122.

Kon, I.S. (2010) Cheesecake on a birch: Sexual culture in Russia. M.: Time. pp. 608.

Ostrovskaya, T.A., Karabulatova, I.S., Khachmafova, Z.R., Lyaucheva, S.A. \& Osipov G.V. The Discourse of the Russian Elite in the ERA "Liquid" Modernity as a Problem of Ethnic, Social and Cultural Security. In the: Mediterranean Journal of Social Science. 2015. Vol 6, No3, S4, May 2015. pp. 147-154.

Pereverzeva, O.V. (2012) "Premarital relations of youth: valuable aspect". The abstract of the thesis on competition of an academic degree of Candidate of Economic Sciences.

Postl, G.S. (2003) Freud and against Freud: Люс Иригарэ // Gender. Culture. German and Russian researches. The collection of articles / Under edition E. Shore, K. Haider. Release 3. M.: RGGU. pp. 309.

Ferkhnem, A. \& Khvein, P. (2001) Personality and social behavior. SPb.: St. Petersburg. pp. 368.

Phillips, Ch. (2002) Feminism and family: the historian - the sociological analysis / Under the editorship of A.I. Antonov. M.: "Graal". pp. 176.

The future of families to 2030 projections, policy challenges and policy options. A Synthesis Report. http://www.oecd.org/ futures/49093502.pdf (дата доступа 10.08.2015).

Cliquet, Robert. Major trends are affecting families in the new Millennium - Western Europe and North America -. http://www.un.org/ esa/socdev/family/Publications/mtcliquet.pdf(дата доступа 10.08.2015).

Höhn, C. (2000), Demographic and Cultural Specificity and Integration of Migrants. 1st Workshop organized by the Federal Institute for Population Research in Co-operation with the Network for Integrated European Population Studies (NIEPS), 10-121 November 2000, Bingen, Germany. Materialien zur Bevölkerungswissenschaft, Heft 103. Wiesbaden: Bundesinstitut für Bevölkerungsforschung. 
Karabulatova, I.S., Khachmafova, Z.R., Bricheva, M.M., Nescheretova, M.T. \& Bersirova, A.K. (2015) Linguopragmatic Aspect of "Search for the Ideal" in the Discourse of Female Fiction as a Reflection of Matrimonial-Demographic and Sexual Behavior in Contemporary Russian Society. Review of European Studies. 2015. Vol. 7. No 6 (2015). - pp.: 35-45.

Karepova, S.G., Karabulatova, I.S., Novikov, V.S., Klemovitsky, S.V., Stratan, D.I. \& Perova A.E. (2015) New Approaches to the Development of Methodology of Strategic Community Planning. In the: Mediterranean Journal of Social Science. 2015. Vol 6, No3, S.6. pp.357-364.

Khachmamova, Z.R., Karabulatova, I.S., Luchinskaya, E.N. \& Osipov G.V. (2015) Gender Features of Discourse of Woman's Literature as a Reflection of Changes in the Modern Society. In the: Mediterranean Journal of Social Science. 2015. Vol 6, No3, S.2, May 2015. pp.: 476-481.

McDonald, P. (2000), Gender Equity, Social Institutions, and the Future of Fertility. Journal of Population Research, 17, 1: 1-16.

Ryazantsev, S.V., Pismennaya, E.E., Karabulatova, I.S. \& Charif, Y.Akramov (2014) Transformation of the sexual and matrimonial behavior of Tajik labor migrants in Russia. In the: Asian Social Science. Vol 10, No.20, 2014, ISSN 1911-2017; E-ISSN 19112025.

Kobersy, I., Barmuta, K., Muradova, S., Dubrova, L., \& Shkurkin, D. (2015). The System of the Methodological Principles of Management of Enterprise Development. Mediterranean Journal Of Social Sciences, 6(3 S4), 25. Retrieved from http://www.mcser.org/ journal/index.php/mjss/article/view/6707

Ryazantsev, S.V., Karabulatova, I.S., Sivoplyasova, S.Yu., Pismennaya, E.E. \& Manshin, R.V. (2015) Modern Aspects of Human Trafficking in the Context of Labor Exploitation and Irregular Labor Migration in the Russian Federation. In the: Mediterranean Journal of Social Science. 2015. Vol 6, No3, S.2, May 2015. pp.: 67-72.

Ryazantsev, S.V., Karabulatova, I.S., Machine, R.V., Pismennaya, E.E. \& Sivoplyasova, S.Yu. (2015) Actual problems of human trafficking in Illegal immigration in the Russian Federation. In the: Mediterranean Journal of Social Science. 2015. Vol 6, No3, S.1, May 2015 (a). pp. 621-626.

Van Peer, C. (2002) Van Peer Desired and Achieved Fertility. In: E. Klijzing and M. Corijn (eds.), Dynamics of Fertility and Partnership in Europe. Insights and Lessons from Comparative Research. Volume II. New York and Geneva: United Nations. pp. 117-142. 